\title{
HUBUNGAN PENGETAHUAN DAN PENERAPAN BREASTFEEDING FATHER TERHADAP PENGELUARAN ASI PADA IBU POST PARTUM
}

\author{
Ni Komang Putri Sinta Devi' ${ }^{1}$ Ratna Dewi Putri², Zarma ${ }^{3}$ \\ 1Program Studi DIV Kebidanan Fakultas kedokteran Universitas Malahayati Bandar Lampung \\ Korespondensi Email : nikomangpsd@gmail.com, \\ 2Dosen Universitas Malahayati Bandar Lampung \\ Email : ratnadewi.070787@gmail.com \\ 3Dinas Kesehatan Propinsi Lampung \\ Email : zarma_h@gmail.com
}

\begin{abstract}
Background Exclusive breast milk (ASI) is breast milk that is given to infants since it is given for six months, without additives .and or replaced with other food or drinks. Coverage of infants to receive exclusive breastfeeding in Lampung Province in 2018 decreases Riskesdas by $32.2 \%$, while this amount is below that approved in Indonesia and is still below the expected target of $80 \%$. Based on the results of the survey in May 2019 In Banjit Health Center, 10 post partum mothers were obtained and 7 were expelled (70\%). The milk was mostly inefficient, and from the number of mothers breastfeeding it was not smooth like this. 4 people did not get help from funds to provide breast milk, as it did not help. household, and always be indifferent when mothers give breast milk.

The purpose of this study is the Relationship between Knowledge and Application of Breastfeeding Fathers to the Expenditures of Breastfeeding in Post Partum Mothers in the Banjit Puskesmas Workplace in Way Kanan Regency in 2019.

The methodes of this study is Quantitative Research, cross sectional study design, the population in this study amounted to 92 people. The sample was 86 people. With a purposive sampling technique sampling. Bivariate data analysis with chi square test.

The results showed that the frequency of adequate breastfeeding was 50 people (58.1\%), good knowledge was 50 people (58.1\%), the application of father's breastfeeding was good as many as 49 people (57.0\%).

Conclusion the application of a breastfeeding father to breastfeeding in post partum mothers in the Way Kanan Health Center Banjit District Work Area in 2019. The t test results obtained $p$ value $0.001<\alpha(0.05)$.

Sugesstion Health workers should be able to provide IEC about procedures for increasing milk production not only to mothers but also to husbands, because the husband's role is very large in the success of breastfeeding.
\end{abstract}

Keywords : Knowledge, application of father's breastfeeding, breastfeeding

\section{ABSTRAK}

Latar Belakang Air Susu Ibu (ASI) eksklusif merupakan air susu ibu yang diberikan kepada bayi sejak dilahirkan selama enam bulan, tanpa menambahkan dan atau mengganti dengan makanan atau minuman lain. Cakupan bayi mendapatkan Air Susu Ibu (ASI) Ekslusif di Provinsi Lampung tahun 2018 menurur Riskesdas sebesar $32,2 \%$, dimana angka ini di bawah cakupan di Indonesia dan masih di bawah target yang diharapkan yaitu 80\%.Berdasarkan hasil presurvey pada bulan Mei 2019 di Puskesmas Banjit didapatkan 10 ibu post partum dan 7 diantaranya (70\%) pengeluaran ASI nya sebagian besar tidak lancar, dan dari jumlah ibu yang pengeluaran ASI nya tidak lancar tersebut 4 orang tidak mendapat dukungan dari suami selama memberikan ASI, seperti suami tidak membantu pekerjaan rumah tangga, dan senantiasa acuh saat ibu memberikan ASI.

Tujuan dari penelitian ini adalah diketahui Hubungan Pengetahuan dan Penerapan Breastfeeding Father Terhadap Pengeluaran ASI Pada Ibu Post Partum Di Wilayah Kerja Puskesmas Banjit Kabupaten Way Kanan Tahun 2019. 
Metode Jenis Penelitian Kuantitatif, rancangan penelitian metode cross sectional, Populasi dalam penelitian ini adalah sebanyak 92 orang. Sampel sebanyak 86 orang. Dengan teknik sampling Purposive Sampling. Analisa data bivariat dengan uji chi square.

Hasil penelitian menunjukan distribusi frekuensi pengeluaran ASI cukup sebanyak 50 orang $(58,1 \%)$, pengetahuan baik sebanyak 50 orang $(58,1 \%)$, penerapan breastfeeding fatheryaitu baik sebanyak 49 orang $(57,0 \%)$.

Kesimpulan Diketahui Ada hubungan pengetahuan dan penerapan breastfeeding father terhadap pengeluaran ASI pada ibu post partum di Wilayah Kerja Puskesmas Banjit Kabupaten Way Kanan Tahun 2019. Hasil uji $t$ didapat $p$ value $0,001<a(0,05)$.

Saran Bagi petugas kesehatan hendaknya dapat memberikan KIE tentang tata cara meningkatkan produksi ASI tidak hanya kepada ibu tetapi kepada suami juga, karena peran suami sangat besar terhadap keberhasilan pemberian ASI.

Kata Kunci : Pengetahuan, penerapan breastfeeding father, pegeluaran ASI

\section{PENDAHULUAN}

World Health Organization (WHO) tahun 2014 menyatakan bahwa jumlah angka kematian bayi (AKB) di Indonesia pada tahun 2012 berada pada angka 26 kematian per 1.000 kelahiran hidup. Jumlah ini masih belum Sesuai dengan tujuan Sustainable Development Goals (SDGs) ke3 target ke-2 yaitu pada tahun 2030. (Ermalena, 2017).

The Lancet Breastfeeding Series, 2016 menyatakan bahwa memberi ASI (Air Susu Ibu) dapat menurunkan angka kematian bayi akibat infeksi sebesar 88\%. Sebanyak 31,36\% dari $37,94 \%$ anak sakit, karena tidak menerima Air Susu lbu Ekslusif. Investasi dalam upaya pencegahan bayi dengan berat lahir rendah (BBLR), Stunting dan meningkatkan inisiasi menyusui dini (IMD) dan ASI (Air Susu Ibu) Eksklusif berkontribusi dalam menurunkan risiko obesitas dan penyakit kronis. (Kemenkes RI, 2017).

Hasil Pemantauan Status Gizi (PSG) tahun 2016 di Indonesia persentase bayi baru lahir yang mendapat IMD pada tahun 2016 sebesar $51,9 \%$ yang terdiri dari $42,7 \%$ mendapatkan Inisiasi Menyusu Dini dalam $<1$ jam setelah lahir, dan 9,2\% dalam satu jam atau lebih. Persentase tertinggi di Provinsi DKI Jakarta (73\%) dan terendah Bengkulu $(16 \%)$. Persentase bayi $0-5$ bulan yang masih mendapat ASI (Air Susu Ibu) eksklusif sebesar $54,0 \%$, sedangkan bayi yang telah mendapatkan ASI (Air Susu lbu) eksklusif sampai usia enam bulan adalah sebesar 29,5\% (Kemenkes RI, 2017), dan berdasarkan hasil Riskesdas 2018 cakupan pemberian ASI (Air Susu Ibu) ekslusif di Indonesia mencapai $37,3 \%$.

Cakupan bayi mendapatkan Air Susu Ibu(ASI) Ekslusif di Provinsi Lampung tahun 2018 menurur Riskesdas sebesar 32,2\%, dimana angka ini di bawah cakupan di Indonesia dan masih di bawah target yang diharapkan yaitu $80 \%$ (Kemenkes RI, 2017).

Persentase bayi yang mendapat ASI ekslusif di Kabupaten Way Kanan pada tahun 2016 sebesar $53.46 \%$ (3.938 dari 7.366 bayi). Capaian ASI (Air Susu Ibu) ekslusif yang terendah adalah Puskesmas Banjit sebesar 40,1\% dimana capaian tersebut masih rendah dari angka cakupan ASI (Air Susu lbu) eksklusif yaitu sebesar 90\% (Profil Dinas Kesehatan Kabupaten Way Kanan, 2016).

Air Susu Ibu (ASI) eksklusif merupakan air susu ibu yang diberikan kepada bayi sejak dilahirkan selama enam bulan, tanpa menambahkan dan atau mengganti dengan makanan atau minuman lain (PP Nomor 33 tahun 2012). ASI merupakan makanan terbaik bagi bayi karena mengandung zat gizi paling sesuai untuk pertumbuhan dan perkembangan bayi (Kemenkes RI, 2017). ASI juga merupakan makanan terbaik yang dapat diberikan ibu kepada bayi yang baru dilahirkannya. ASI jika diberikan dengan baik dan benar sebagai makanan tunggal dapat memenuhi kebutuhan bayi untuk tumbuh secara optimal secara optimal sampai enam bulan (Ikatan Dokter Anak Indonesia, 2013).

Ikatan Dokter Anak Indonesia (IDAI) tahun 2013 menyatakan bahwa dalam kenyataannya, pemberian ASI (Air Susu Ibu) eksklusif selama enam bulan pertama kehidupan bayi memiliki banyak kendala, seperti ibu kurang memahami tata laksana laktasi yang benar, ibu bekerja, dan produksi ASI (Air Susu Ibu) yang kurang. Beberapa faktor diduga menyebabkan berkurangnya produksi ASI (Air Susu Ibu), yaitu faktor menyusui, faktor psikologis ibu, faktor fisik ibu, dan faktor bayi. Faktor psikologis seperti stres, khawatir, ketidakbahagiaan ibu pada periode menyusui sangat berperan dalam menyukseskan pemberian ASI (Air Susu lbu) eksklusif (IDAl, 2013). 
Peran keluarga terutama suami sangatlah dibutuhkan oleh seorang ibu. Ibuakan merasa terbantu atau merasa didukung dengan adanya keterlibatan peran didalamnya. Pernyataan tersebut di dukung oleh penelitian Marheni (2018) tentang breastfeeding father Dalam Pengambilan Keputusan Melaksanakan ASI (Air Susu Ibu) Eksklusif Di Puskesmas Ungaran, hasil penelitian menunjukkan Penerapan Breastfeeding father menurut penilaian Ibu hamil sebanyak $47,2 \%$ dan yang tidak menerapkan breastfeeding father yaitu $52,8 \%$. Ibu yang memutuskan melaksanakan ASI (Air Susu lbu) Eksklusif sebanyak 45,3\% dan ibu yang memutuskan tidak melaksanakan ASI (Air Susu Ibu) Eksklusif yaitu 54,7\%. Ada hubungan yang signifikan antara breastfeeding father dengan pengambilan keputusan ibu untuk melaksanakan ASI Eksklusif di wilayah kerja Puskesmas Ungaran dengan $p$-value $0,004<a(0,05)$.Dukungan orang terdekat khusunya suami sangat dibutuhkan dalam mendukung ibuselama memberikan ASI-nya sehingga memunculkan istilah breastfeeding father atauayah menyusui. Jika ibu merasa didukung, dicintai, dan diperhatikan maka akanmuncul emosi positif yang akan meningkatkan produksi hormon oksitosin sehinggaproduksi ASI (Air Susu lbu) pun lancar (Iswari, 2018).

Destriatania (2010) mengungkapkan hasil penelitian yang dilakukan di wilayah urban Jakarta Selatan bahwa praktik pemberian ASI (Air Susu Ibu) eksklusif cenderung 1,4 kali lebih tinggi pada ayah yang memiliki pengetahuan postnatal tinggi dibandingkan ayah yang memiliki pengetahuan postnatal rendah.

Hasil penelitian yang dilakukan oleh Kusumayanti (2017) menunjukkan analisis statistik dilakukan secara bivariat dengan uji korelasi Spearman. Prevalensi pemberian ASI (Air Susu Ibu) eksklusif sebesar 21,2\%. Sebagian besar suami mendukung pemberian ASI (Air Susu Ibu) eksklusif $(72,7 \%)$. Berdasarkan uji tabulasi silang diketahui bahwa dukungan suami lebih besar peluangnya $(27,1 \%)$ terhadap pemberian ASI (Air Susu lbu) eksklusif dibandingkan suami yang tidak mendukung $(5,6 \%)$.

Berdasarkan hasil presurvey pada bulan Mei 2019 di Puskesmas Banjitdidapatkan 10 ibu post partum dan 7 diantaranya( $70 \%$ ) pengeluaran ASI nya sebagian besar tidak lancar, dan dari jumlah ibu yang pengeluaran ASI nya tidak lancar tersebut 4 orang tidak mendapat dukungan dari suami selama memberikan ASI, seperti suami tidak membantu pekerjaan rumah tangga, dan senantiasa acuh saat ibu memberikan ASI.
Oleh karena itu, peneliti tertarik untuk meneliti lebih dalam terkait HubunganPengetahuan dan Penerapan Breastfeeding Father Terhadap Pengeluaran ASI Pada Ibu Post Partum Di Wilayah Kerja Puskesmas Banjit Kabupaten Way Kanan Tahun 2019.

\section{METODOLOGI PENELITIAN}

Jenis penelitian ini merupakan penelitian kuantitatif yaitu penelitian yang mencoba menggali bagaimana dan mengapa fenomena kesehatan itu terjadi. Penelitian ini merupakan penelitian analitik, yaitu penelitian ilmiah yang sistematis terhadap bagian-bagian dan fenomena serta hubungan hubungannya (Notoatmodjo, 2018). Penelitiantelah dilakukan di Wilayah Kerja Puskesmas Banjit Kabupaten Way Kananpada Bulan Juli Tahun 2019. Jenis penelitian yang digunakan dalam penelitian ini adalah penelitian secara analitik dengan menggunakan rancangan cross-sectional yang merupakan rancangan penelitian dengan menggunakan pengukuran atau pengamatan pada saat bersamaan (sekali waktu) antara variabel bebas (faktor resiko) dengan variabel tergantung (efek)(Notoatmodjo, 2018). Dimana dilakukan pengukuran variabel pengetahuan dan penerapanbreastfeeding fathersebagai variabel independen dengan pengeluaran ASI sebagai variabel dependen dikumpulkan datanya dalam waktu yang bersamaan atau satu kali pengambilan data.

Populasi dalam penelitian ini adalah seluruh ibu post partumdi Wilayah Kerja Puskesmas Banjit Kabupaten Way Kanan yaitu sebanyak 92 orang.Sampel adalah sebagian atau wakil populasi yang diteliti (Arikunto, 2019). Maka sampel dalam penelitian ini sebanyak 86 orang.

Pengambilan sample penelitian ini dilakukan dengan menggunakan teknik purposve sampling yaitu mengambil sampel berdasarkan kriteria yang peneliti tentukan(Notoatmodjo, 2018).

\section{Persetujuan KEPK}

Melakukan pengujian KEPK yaitu meliputi melakukan inform concent kepada calon responden, mengisi protokol etik penelitian kesehatan, mengisi KEPPKN-2017 yaitu meliputi penerapan prinsip 3 ke 7 butir standar kriteria/ dasar pengambilan keputusan persetujuan usulan protokol layak etik, setelah dinyatakan lulus uji KEPK dengan nomer surat (NO. 313/ EC/KEPUNMAL///2019) peneliti melakukan penelitian dengan melakukan pengambilan data kepada responden penelitian. 
HASIL PENELITIAN

Tabel 1.

Karakteristik Responden Berdasarkan Usia dan Paritas

\begin{tabular}{lcc}
\hline Usia Responden & Frekuensi & $\begin{array}{c}\text { Persentase } \\
(\%)\end{array}$ \\
\hline Usia < 20 Tahun & 0 & 0 \\
Usia 20-35 Tahun & 86 & 100,0 \\
Usia > 35 Tahun & 0 & 0 \\
\hline Paritas & & \\
\hline Paritas 1 & 20 & 23.25 \\
Paritas 2 & 41 & 47.67 \\
\hline Paritas 3 & 25 & 29.06 \\
\hline
\end{tabular}

Berdasarkan tabel 1 terlihat bahwa dari 86 responden (100\%) usia responden berusia 20-35 Tahun dan bahwa dari 86 responden sebagian besar responden paritas ke 2 yaitu sebanyak 41 orang $(47,67 \%)$.

\section{Analisis Univariat}

Tabel 2

Distribusi frekuensi pengeluaran ASI pada ibu post partum di Wilayah Kerja Puskesmas Banjit Kabupaten Way Kanan Tahun 2019.

\begin{tabular}{cccc}
\hline No & $\begin{array}{c}\text { Pengeluaran } \\
\text { ASI }\end{array}$ & Frekuensi & $\begin{array}{c}\text { Persentase } \\
(\%)\end{array}$ \\
\hline 1. & Cukup & 50 & 58,1 \\
2. & Tidak Cukup & 36 & 41,9 \\
\hline & Jumlah & 86 & 100,0 \\
\hline
\end{tabular}

Berdasarkan tabel2 diatas dapat diketahui bahwa dari 86 responden, diperoleh hasil sebagian besar pengeluaran ASI cukup yaitu sebanyak 50 orang $(58,1 \%)$.

Tabel 3.

Distribusi Frekuensi Pengetahuan Pada Ibu Post Partum Di Wilayah Kerja Puskesmas Banjit Kabupaten Way Kanan Tahun 2019.

\begin{tabular}{clcc}
\hline No & Pengetahuan & Frekuensi & $\begin{array}{c}\text { Persentase } \\
(\%)\end{array}$ \\
\hline 1. & Baik & 50 & 58,1 \\
2. & Kurang Baik & 36 & 41,9 \\
\hline & Jumlah & 86 & 100,0 \\
\hline
\end{tabular}

Berdasarkan table 3 diatas dapat diketahui bahwa dari 86 responden penelitian, diperoleh hasil sebagian besar responden memiliki pengetahuan baik yaitu sebanyak 50 orang $(58,1 \%)$.

Tabel 4.

Distribusi Frekuensi Breastfeeding Father Pada Ibu Post Partum Di Wilayah Kerja Puskesmas Banjit Kabupaten Way Kanan Tahun 2019.

\begin{tabular}{llcc}
\hline No & $\begin{array}{c}\text { Breastfeeding } \\
\text { Father }\end{array}$ & Frekuensi & $\begin{array}{c}\text { Persentase } \\
(\%)\end{array}$ \\
\hline 1. & Baik & 49 & 57,0 \\
2. & Tidak Baik & 37 & 43,0 \\
\hline & Jumlah & 86 & 100,0 \\
\hline
\end{tabular}

Berdasarkan table 4 . diatas dapat diketahui bahwa dari 86 responden penelitian, diperoleh hasil sebagian besar respondenmemiliki breastfeeding baik yaitu sebanyak 49 orang $(57,0 \%)$.

\section{Analisis Bivariat}

Tabel 5.

Hubungan pengetahuan terhadap pengeluaran ASI pada ibu post partum di Wilayah Kerja Puskesmas Banjit Kabupaten Way Kanan Tahun 2019

\begin{tabular}{ccccccccc}
\hline \multirow{2}{*}{$\begin{array}{c}\text { Variabel } \\
\text { Pengetahuan }\end{array}$} & \multicolumn{4}{c}{ Pengeluaran ASI } & \multicolumn{2}{c}{ Jumlah } & \multirow{2}{*}{ p-value } & \multirow{2}{*}{ OR } \\
\cline { 2 - 6 } & $\mathrm{N}$ & $\%$ & $\mathrm{~N}$ & $\%$ & $\mathrm{~N}$ & $\%$ & & Cl (95\%) \\
\hline Baik & 38 & 76,0 & 12 & 24,0 & 50 & 100,0 & \multirow{2}{*}{0,001} & 6,333 \\
Kurang Baik & 12 & 33,3 & 24 & 66,7 & 36 & 100,0 & & $(2,451-16,367)$ \\
\hline
\end{tabular}

Berdasarkan tabel 5 diatas terlihat bahwa dari 50 responden responden yang memiliki pengetahuan baik dan pengeluaran ASI cukup sebanyak 38 orang $(76,0 \%)$ dan tidak cukup sebanyak 12 orang $(24,0 \%)$, sedangkan dari 36 responden yang memiliki pengetahuan kurang baik dan pengeluaran ASI cukup sebanyak 12 orang
$(33,3 \%)$ dan yang pengeluaran ASI tidak cukup sebanyak 24orang $(66,7 \%)$.

Hasil analisis lebih lanjut dengan menggunakan analisis data chi square dengan tingkat kepercayaan $95 \%$ di dapatkan $p$-value 0,001 dan a 0,05 . Karena nilai $p$-value $<a$ maka $\mathrm{H}_{0}$ ditolak dan $\mathrm{Ha}$ diterima atau berarti ada 
hubunganpengetahuan terhadap pengeluaran ASI pada ibu post partum di Wilayah Kerja Puskesmas Banjit Kabupaten Way Kanan Tahun 2019. Hasil analisis juga diperoleh nilai Odds Ratio sebesar 6,333 yang artinya ibu yang memiliki pengetahuan kurang baik memiliki resiko 6 kali mengalami pengeluaran ASI tidak cukup dibandingkan dengan ibu yang memilikipengetahuan baik. Sedangkan $\mathrm{Cl}$ (Convident Interval) variabel pengetahuan mengenai breastfeeding father adalah 7,624 yang berarti tingkat kepercayaan termasuk kategori rendah, dikarenakan sampel kurang dari 100.

Tabel 6.

Hubungan penerapan breastfeeding father terhadap pengeluaran ASI pada ibu post partum di Wilayah Kerja Puskesmas Banjit Kabupaten Way Kanan Tahun 2019

\begin{tabular}{ccccccccc}
\hline Variabel & \multicolumn{4}{c}{ Pengeluaran ASI } & \multirow{2}{*}{ Jumlah } & \multirow{2}{*}{ p-value } & \multirow{2}{*}{ OR } \\
\cline { 2 - 6 } Breastfeeding & \multicolumn{3}{c}{ Cukup } & \multicolumn{2}{c}{ Tidak Cukup } & & & \\
\cline { 2 - 7 } Father & $\mathrm{N}$ & $\%$ & $\mathrm{~N}$ & $\%$ & $\mathrm{~N}$ & $\%$ & & \\
\hline Baik & 43 & 87,8 & 6 & 12,2 & 49 & 100,0 & \multirow{2}{*}{0,001} & 10,714 \\
Tidak Baik & 7 & 18,9 & 30 & 81,1 & 37 & 100,0 & & $(7,382-18,549)$ \\
\hline
\end{tabular}

Berdasarkan tabel 4.6 diatas terlihat bahwa dari 49 responden yang memiliki breastfeeding father baik dan pengeluaran ASI cukup sebanyak 43orang $(87,8 \%)$ dan tidak cukup sebanyak 6 orang $(12,2 \%)$, sedangkan dari 37 responden yang memiliki breastfeeding tidak baik dan pengeluaran ASI cukup sebanyak 7 orang $(18,9 \%)$ dan yang pengeluaran ASI tidak cukup sebanyak 30 orang $(81,1 \%)$.

Hasil analisis lebih lanjut dengan menggunakan analisis data chi square dengan tingkat kepercayaan $95 \%$ di dapatkan $p$-value 0,001 dan a 0,05 . Karena nilai $p$-value $<a$ maka $\mathrm{H}_{0}$ ditolak dan $\mathrm{Ha}$ diterima atau berarti ada hubungan breastfeeding father terhadap pengeluaran ASI pada ibu post partum di Wilayah Kerja Puskesmas Banjit Kabupaten Way Kanan Tahun 2019. Hasil analisis juga diperoleh nilai Odds Ratio sebesar 10,714 yang artinya ibu yang memiliki breastfeeding father tidak baik memiliki resiko 10 kali mengalami pengeluaran ASI tidak cukup dibandingkan dengan ibu yang memiliki breastfeeding father baik. Sedangkan $\mathrm{Cl}$ (Convident Interval) variabel penerapan adalah 0,453 yang berarti tingkat penerapan breastfeeding father termasuk kategori rendah, dikarenakan sampel kurang dari 100.

\section{PEMBAHASAN}

\section{Bivariat}

Hubungan pengetahuan terhadap pengeluaran ASI pada ibu post partum di Wilayah Kerja Puskesmas Banjit Kabupaten Way Kanan Tahun 2019.

Berdasarkan hasil penelitian diatas terlihat bahwa dari 50 responden yang memiliki pengetahuan baik dan pengeluaran ASI cukup sebanyak 38 orang $(76,0 \%)$ dan tidak cukup sebanyak 12 orang $(24,0 \%)$, sedangkan dari 36 responden yang memiliki pengetahuan kurang baik dan pengeluaran ASI cukup sebanyak 12 orang $(33,3 \%)$ dan yang pengeluaran ASI tidak cukup sebanyak 24 orang $(66,7 \%)$.

Hasil analisis lebih lanjut dengan menggunakan analisis data chi square dengan tingkat kepercayaan $95 \%$ di dapatkan $p$-value 0,001 dan a 0,05 . Karena nilai $p$-value <a maka $\mathrm{H}_{0}$ ditolak dan $\mathrm{Ha}$ diterima atau berarti ada hubungan pengetahuan terhadap pengeluaran ASI pada ibu post partum di Wilayah Kerja Puskesmas Banjit Kabupaten Way Kanan Tahun 2019. Hasil analisis juga diperoleh nilai Odds Ratio sebesar 6,333yang artinya ibu yang memiliki pengetahuan kurang baik memiliki resiko 6 kali mengalami pengeluaran ASI tidak cukup dibandingkan dengan ibu yang memiliki pengetahuan baik.

Menurut teori pengetahuan merupakan hasil dari tahu dan ini terjadi setelah seseorang melakukan pengindraan melalui pancaindra terhadap suatu objek tertentu. Pengindraan terjadi melalui pancaindra manusia yaitu indra penglihatan, pendengaran, penciuman, rasa dan raba. Sebagian besar pengetahuan diperoleh melalui indra penglihatan dan pendengaran (Notoatmodjo, 2018).

ASI adalah suatu emulsi lemak dalam larutan protein, laktosa dan garam-garam organik yang disekresi oleh kedua belah payudara ibu, sebagai makanan utama bagi bayi. ASI bukan minuman, namun ASI merupakan satu-satunya makanan tunggal paling sempurna bagi bayi hingga berusia 6 bulan. ASI cukup mengandung seluruh zat gizi yang dibutuhkan bayi. Selain itu, secara alamiah ASI dibekali enzim pencerna susu sehingga organ pencernaan bayi mudah mencerna 
dan menyerap gizi ASI. Sistim pencernaan bayi usia dini belum memiliki cukup enzim pencerna makanan, oleh karena itu berikan pada bayi ASI saja hingga usia 6 bulan, tanpa tambahan minuman atau makanan apapun (Maryunani, 2012).

Hasil penelitian ini sejalan dengan penelitian yang telah dilakukan oleh Marheni (2018) tentang breastfeeding father Dalam Pengambilan Keputusan Melaksanakan Asi Eksklusif Di Puskesmas Ungaran, hasil penelitian menunjukkan Penerapan Breastfeeding father menurut penilaian Ibu hamil sebanyak $47,2 \%$ dan yang tidak menerapkan breastfeeding father yaitu $52,8 \%$. Ibu yang memutuskan melaksanakan ASI Eksklusif sebanyak $45,3 \%$ dan ibu yang memutuskan tidak melaksanakan ASI Eksklusif yaitu 54,7\%. Ada hubungan yang signifikan antara breastfeeding father dengan pengambilan keputusan ibu untuk melaksanakan ASI Eksklusif di wilayah kerja Puskesmas Ungaran dengan $p$-value $0,004<a$ $(0,05)$.

Menurut pendapat peneliti berdasarkan hasil penelitian, bahwa ada hubungan pengetahuan yang baik terhadap pengeluaran ASI pada ibu post partum di wilayah Puskesmas Kecamatan Banjit Kabupaten Way Kanan. Hal tersebut disebabkan oleh mayoritas ibu yang ada di wilayah setempat memiliki informasi yang baik tentang pengeluaran ASI dikarenakan sering mengikuti posyandu serta mendapat penyuluhan tentang ASI oleh tenaga kesehatan setempat. Dan juga usia produktif yaitu 20-35 tahun berpengaruh terhadap pengeluaran ASI dikarenakan responden di usia produktif memiliki rasa ingin tau tentang pengeluaran ASI cukup baik.

Hubungan breastfeeding father terhadap pengeluaran ASI pada ibu post partum di Wilayah Kerja Puskesmas Banjit Kabupaten Way Kanan Tahun 2019.

Berdasarkan hasil penelitian diatas terlihat bahwa dari 49 responden yang memiliki breastfeeding father baik dan pengeluaran ASI cukup sebanyak 43 orang $(87,8 \%)$ dan tidak cukup sebanyak 6 orang $(12,2 \%)$, sedangkan dari 37 responden yang memiliki breastfeeding tidak baik dan pengeluaran ASI cukup sebanyak 7 orang $(18,9 \%)$ dan yang pengeluaran ASI tidak cukup sebanyak 30 orang $(81,1 \%)$.

Hasil analisis lebih lanjut dengan menggunakan analisis data chi square dengan tingkat kepercayaan $95 \%$ di dapatkan $p$-value 0,001 dan a 0,05 . Karena nilai $p$-value $<a$ maka $\mathrm{H}_{0}$ ditolak dan $\mathrm{Ha}$ diterima atau berarti ada hubungan breastfeeding father terhadap pengeluaran ASI pada ibu post partum di Wilayah Kerja Puskesmas Banjit Kabupaten Way Kanan Tahun 2019. Hasil analisis juga diperoleh nilai Odds Ratio sebesar 10,714 yang artinya ibu yang memiliki breastfeeding father tidak baik memiliki resiko 10 kali mengalami pengeluaran ASI tidak cukup dibandingkan dengan ibu yang memiliki breastfeeding father baik.

Menurut teori Breastfeeding father (Ayah ASI) merupakan sebuah fenomena yang menggambarkan keterlibatan ayah dalam proses pemberian ASI eksklusif. Ayah ASI lebih lengkap dijelaskan sebagai suatu pola pikir dan tindakan seorang ayah yang mendukung, membantu, mendorong, dan mengawal hubungan antara ibu dan bayi dalam memberikan ASI sebagai makanan utama bagi bayi mereka (Syamsiah, 2010).

Breastfeeding father (Ayah ASI) adalah paduan pola pikir dan tindakan seorang ayah yang mendukung proses menyusui dari istri (ibu) ke anaknya. Bukan label, julukan, apalagi pangkat yang bisa dicapai dengan target tertentu, karena penerapanya bisa sangat relatif, bahkan sulit dirumuskan (Roesli, 2013).

Ayah ASI (breastfeeding father) adalah keterlibatan ayah dalam memberikan dukungan emosional dan fisik kepada ibu menyusui sehingga Keterlibatan ayah tersebut turut menentukan kelancaran refleks pengeluaran ASI (let down reflex) yang dipengaruhi emosi ibu. Dukungan suami merupakan salah satu faktor yang mempengaruhi keberhasilan ibu dalam pemberian ASI eksklusif. Cara terbaik yang dapat dilakukan suami dalam memberi dukungan kepada ibu menyusui adalah dengan berperan sebagai breastfeeding father. Breastfeeding father adalah dukungan penuh seorang suami sebagai ayah kepada istrinya agar dapat berhasil dalam proses menyusui (Ariani, 2010).

Seorang ayah mempunyai peran yang sangat penting dalam keberhasilan menyusui. Pasangan yang saling mendukung adalah faktor yang menentukan kesuksesan proses menyusui. Dengan kata lain keberhasilan menyusui tidak terlepas dan usaha para ayah untuk menjadi Breastfeeding father(Ariani,2010).

Air susu ibu (ASI) merupakan suatu cairan hidup yang dapat berubah dan memberi respon terhadap kebutuhan bayi seiring dengan pertumbuhannya. ASI adalah suatu cairan yang terbentuk dari campuran dua zat yaitu lemak dan air yang terdapat dalam larutan protein, laktosa dan garam-garam anorganik yang dihasilkan oleh kelenjar payudara ibu, dan bermanfaat sebagai makanan bayi (Muchtar dkk, 2014). 
Hasil penelitian ini sejalan dengan penelitian yang telah dilakukan oleh Marheni (2018) tentang breastfeeding father Dalam Pengambilan Keputusan Melaksanakan Asi Eksklusif Di Puskesmas Ungaran, hasil penelitian menunjukkan Penerapan Breastfeeding father menurut penilaian Ibu hamil sebanyak $47,2 \%$ dan yang tidak menerapkan breastfeeding father yaitu 52,8 \%. Ibu yang memutuskan melaksanakan ASI Eksklusif sebanyak $45,3 \%$ dan ibu yang memutuskan tidak melaksanakan ASI Eksklusif yaitu 54,7\%. Ada hubungan yang signifikan antara breastfeeding father dengan pengambilan keputusan ibu untuk melaksanakan ASI Eksklusif di wilayah kerja Puskesmas Ungaran dengan $p$-value $0,004<a$ $(0,05)$.

Menurut pendapat peneliti berdasarkan hasil penelitian responden yang memiliki pengeluaran ASI yang baik disebabkan karena adanya peran suami dalam memberikan motivasi kepada istri yang sedang menyusui. Motivasi ini dapat mengurangi emosional, rasa lelah saat menyusui dan rasa ingin berhenti menyusui. Serta pada saat masa kehamilan suami ikut berperan dalam pencarian informasi tentang ASI. Sehingga pada saat suami memberikan motivasi dan ikut berperan dalam mencari informasi, istri dapat merasa bahagia serta merasa diperhatikan sehingga pengeluaran ASInya menjadi banyak.

\section{KESIMPULAN}

Berdasarkan hasil penelitian yang telah dilakukan, maka dapat disimpulkan hasil penelitian adalah sebagai berikut:Pengeluaran ASI pada ibu post partum di Wilayah Kerja Puskesmas Banjit Kabupaten Way Kanan Tahun 2019, yaitu sebagian besar pengeluaran ASI pada ibu post partum pada kategori cukup sebanyak 50 orang (58,1\%).Pengetahuan pada ibu post partum di Wilayah Kerja Puskesmas Banjit Kabupaten Way Kanan Tahun 2019, yaitu sebagian besar ibu post partum memiliki pengetahuan baik sebanyak 50 orang $(58,1 \%)$.Penerapan breastfeeding father di Wilayah Kerja Puskesmas Banjit Kabupaten Way Kanan Tahun 2019 yaitu sebagian besar ibu post partum dengan breastfeeding fatherbaik sebanyak 49 orang $(57,0 \%)$.Ada hubungan pengetahuan terhadap pengeluaran ASI pada ibu post partum di Wilayah Kerja Puskesmas Banjit Kabupaten Way Kanan Tahun 2019, didapatkan $P$-value $=0,001<a$ 0,05 . Ada hubungan penerapan breastfeeding father terhadap pengeluaran ASI pada ibu post partum di Wilayah Kerja Puskesmas Banjit Kabupaten Way Kanan Tahun 2019, didapatkan $P$ value $=0,001<a 0,05$.

\section{SARAN}

Berdasarkan kesimpulan yang diperoleh, maka dapat disarankan untuk :Bagi responden disarankan agar mengajak suami untuk mengikuti kelas ibu hamil sebagai salah satu cara untuk meningkatkan pengeluaran ASI.Bagi petugas kesehatan hendaknya dapat memberikan KIE tentang tata cara meningkatkan produksi ASI tidak hanya kepada ibu tetapi kepada suami juga, karena peran suami sangat besar terhadap keberhasilan pemberian ASI.Bagi tempat penelitian hendaknya dapat meningkatkan informasi bagi tempat penelitian bahwa dengan meningkatkan pengetahuan dan breastfeeding father sebagai salah satu cara meningkatkan produksi ASI pada ibu nfas melalui media seperti leaflet dan poster, dan juga breastfeeding father dapat dimasukan dalam protap membantu ibu dalam menentukan keberhasilan pemerian ASI.Bagi peneliti selanjutnya dapat menambah wawasan penelitian selanjutnya dan dapat dijadikan bahan referensi guna melakukan penelitian yang sama, dan diharapkan peneliti selanjutnya yang akan melakukan penelitian yang sama dapat menambah variabel - variabel yang lain seperti usia, pengetahuan dan lingkungan sehingga diperoleh hasil penelitian yang lebih baik lagi.

\section{DAFTAR PUSTAKA}

Ariani. (2010). Ibu susui aku, bayi sehat dan cerdas dengan ASI. Bandung: Khasanah Intelektual

Arikunto, S. (2019). Prosedur penelitian.

Destriatania (2010) Hubungan Antara Pengetahuan Dan Sikap Ayah Terhadap Praktik Inisiasi Menyusu Segera Dan Pemberian ASI Eksklusif Di Wilayah Urban Jakarta Selatan Tahun 2007. ( Analisis data sekunder penelitian yang berjudul "Peran Ayah Dalam Optimalisasi Praktik Pemberian ASI: Sebuah Studi di Daerah Urban Jakarta tahun 2007".

Ermalena, (2017). Indikator Kesehatan SDGs Di Indonesia http://ictohtcscindonesia.com/wpcontent/uploads/2017/05/Dra.-ErmalenaIndikator-Kesehatan-SDGs-DiIndonesia.pdf

Indonesia, I. D. A. (2013). Nilai nutrisi air susu ibu.

INDONESIA, P. R. Peraturan Pemerintah Republik Indonesia nomor 33 tahun 2012 tentang pemberian air susu ibu eksklusif.

Iswati (2018). Gambaran Pengetahuan Suami Dari Ibu Menyusui (0-6 Bulan) Tentang ASI Eksklusif Di Wilayah Kerja Puskesmas 
Dermayu Kabupaten Seluma Tahun 2017. https://jurnal.unived.ac.id/index.php/JM/arti cle/download/505/443/

Kemenkes RI, (2017). Profil Kesehatan Indonesia 2016

Marheni (2018) Breastfeeding father Dalam Pengambilan Keputusan Melaksanakan Asi Eksklusif Di Puskesmas Ungaran. journal.stikeseub.ac.id/index.php/jkeb/articl e/view/267

Maryunani. (2012). Inisisi Menyusui Dini, ASI Eklusif dan Manajemen Laktasi. Jakarta : EGC

Muchtar, dkk (2014). Buku Ajar Kesehatan Ibu dan Anak. Jakarta Selatan: Pusat Pendidikan dan Pelatihan Tenaga Kesehatan
Notoatmodjo. (2018). Metodologi Penelitian Kesehatan. Jakarta : PT. Rineka Cipta.

Pemerintah Pusat. PP 33 tentang pemberian ASI eksklusif. 2012

Roesli, Utami. (2013). Mengenal ASI Eksklusif. PT.Pustaka Pembangunan Swadaya Nusantara.

Syamsiyah S., (2011). Tingkat Pengetahuan Suami Mengenai ASI Eksklusif Dan hubungannya Dengan Penerapan Breasstfeeding Father. Jurnal Kesehatan Prima Vol. 3 No.1 Januari 2011

Wahyuningsih, D. (2013). Dukungan Suami dalam Pemberian ASI Eksklusif. Jurnal Keperawatan Maternitas, 1(2). 